\title{
An Empirical Investigation on Taxi Hailing Mobile App Adoption: A Structural Equation Modelling
}

\author{
Herman Fassou Haba \\ Lord Ashcroft International Business School, Anglia Ruskin University, Cambridge, \\ United Kingdom, FTMS Malaysia Centre
}

\section{Omkar Dastane (Corresponding author)}

School of Accounting \& Business Management, FTMSGlobal Malaysia, Cyberjaya, Malaysia. Senior Lecturer, Head - Centre for Postgraduate Studies, School of Accounting \& Business Management, FTMS Global Malaysia, Block 3420, Persiaran Semarak Api, Cyber 4, Cyberjaya, Selangor, Malaysia

Tel: 6010-2046-941Ｅ-mail: omkar.dastane@gmail.com

Received: February 13, 2018

doi:10.5296/bms.v9i1.13006
Accepted: February 28, 2018 Published: April 16, 2018

URL: https://doi.org/10.5296/bms.v9i1.13006

\begin{abstract}
This empirical investigation aims to determine the factors leading to the adaptation of Taxi Hailing Mobile Apps among Malaysian consumers using the theory of Venkatesh et al. (2003) user theory of acceptance and use of technology (UTAUT). The adopted framework has four independent variables namely performance expectancy, effort expectancy, social influence and facilitating conditions. Dependent variables include behavioural intension and user behaviour. The study follows exploratory research design and quantitative research method. Primary data is collected using online Google survey questionnaire. The target population of this research study is international and local in Malaysia who makes use of taxi hailing app in order to satisfy their transportation needs. Convenience sampling technique is used to collect data from a sample of 202 respondents. Confirmatory Factors Analysis (CFA) and Structural Equation Modelling (SEM) are used in order to answer the research questions. Findings show that Performance expectancy, social influence and behaviour intension has positive influence on user behaviour while effort expectancy and behavioural intension has no influence. For scholars and researchers, understandably this research study opens the gate way of the


application of UTAUT on information system (IS) apps that had been recently created.

Keywords: Technology Acceptance, M-Commerce, Mobile Apps, Online User Behaviour 


\section{Introduction}

M-commerce known as mobile commerce is referred to business activities operated by a mobile cell phone or smartphone. As mankind reached the era of digitalization where access to internet is the simplest way to acquire information, smartphone has never been in great use than nowadays. According to Kemp (2017) statistical report, almost 3 billion people will be using smartphone in 2020, thus, its lead to M-commerce booming since 2010. In 2013 and 2014, M-commerce investment surpasses the $\$ 1.2$ billion worldwide making a promising industry due to the web visualized experience and it is no secret that companies have capitalized on this trend by using photo rich content to attract large user bases (Nakache and Carter, 2015). The purpose of this study is to analyse online taxi companies market insight and to determine the impact of factors impacting user adaptation of taxi call app in Malaysia.

Since the world has been witnessing of the popularity of online taxi companies and customer intention of adopting and using them, several researches have been done all around the world concerning online taxi companies and taxi call app. First of all, most of the researches have been done in developing countries such as the study of Chan et al (2016) on taxi app market analysis in Hong Kong, Keong (2015) study on Malaysian taxi drivers adaptation of online taxi companies apps, Peng et al (2014) exploring factors affecting the user adoption of call taxi app in china, Kumar and Kumar (2016) study on selection of cab services in India. Understandably, there have been a lot of helpful hands from researchers in the developed world such as Rajabion (2015) study on America mobile service adaptation, Liu (2014) study with technology acceptance model (TAM) for the acceptance of taxi-hailing app in Sweden, Rayle et al (2014) research study on app-based on demand ride service in USA. Basically, most of these researches are done in developed and developing countries, none of it is done in third world countries due to lack of technology, infrastructure and non-ease of business. Though, this research study will make use of Venkatesh et al (2003) user theory of acceptance and use of technology (UTAUT) whether it can fit consumer insight in Malaysia for the purpose of using call taxi app, and find the differences of consumers using UberX and GrabCar.

Wharton's David Bell notes four distinctive characteristics of an app mobile: first of all it is uniquely tied to one user, second of all, it is virtually always "on” given it is typically carried everywhere, third of all, it allows for immediate consumption of service because it is in effect a channel of distribution with a payment system and fourthly it is highly interactive given it allows for geo-tracking and usability. However, seven of every 10 Malaysian consumers owned a smartphone in 2015, creating a major opportunity for online taxi companies to build apps which can reach the target. According to Haba et al. (2017), Malaysian professionals get influenced by perceived usefulness while making purchase of smartphones and when it comes to South East Asian young adults, social influence plays crucial role in developing purchase intention (Zahid \& Dastane, 2016). Nevertheless, in this promising industry of M-commerce, there is a battle of competition which is making difficult for UberX and GrabCar to gain competitive advantage. The emergence of call taxi app has increased 
competitive pressure, and competitors are continually adding features, sharpening price and try to offer much better value proposition to their customers. In this war, traditional taxi drivers have been left away from competition and now the battle is being too intense between UberX Company and GrabCar Company in order to provide better proposition (Chew, 2016). Moreover, in competition between the two giants online taxi companies each one is trying to find out which model can fit their customer requirement in order to retain the loyal ones and gain more ones.

The aim of this research study is to determine the factors leading to the adaptation of taxi calling app among Malaysian consumers using the theory of Venkatesh et al (2003) user theory of acceptance and use of technology (UTAUT). The research objectives are: To find the impact of performance expectancy on behavioral intention of adopting taxi hailing app in Malaysia. To find the impact of effort expectancy on behavioral intention of adopting taxi hailing app in Malaysia. To find the impact of social influence on behavioral intention of adopting taxi hailing app in Malaysia. To find the impact of facilitating condition on user behavior of adopting taxi hailing app in Malaysia. Corresponding research questions are: What is the impact of performance expectancy on behavioral intention of adopting taxi hailing app in Malaysia? What is the impact of effort expectancy on behavioral intention of adopting taxi hailing app in Malaysia? What is the impact of social influence on user behavioral of adopting taxi hailing app in Malaysia? What is the impact of facilitating condition on user behavior of adopting taxi hailing in Malaysia?

\section{Literature Review}

\subsection{Definitions of Key Terms}

UberX is the most basic U.S private car service that has been offered around several countries in the world, it is recognized as the lowest cost option car service which is very affordable (Farrell, 2013). GrabCar is one of the largest taxis hailing mobile application offered in 22 Asian cities across six countries including Malaysia, Singapore, Philippines, Indonesia and Thailand (Asian Business Insights, 2015). An online taxi company, also known as a taxicab, is a type of vehicle for hire with a driver, used by a single passenger or small group of passengers, often for a non-shared ride. A taxicab conveys passengers between locations of their choice. The unified theory of acceptance and use of technology (UTAUT) is a technology acceptance model formulated by Venkatesh and others in "User acceptance of information technology: Toward a unified view". The UTAUT aims to explain user intentions to use an information system and subsequent usage behaviour (Venkatesh et al, 2003).

\subsection{Literature Gap}

In information technology (IT) and technology acceptance model (TAM) individual adaptation has been a critical factor for ICT companies. In this field of technology acceptance model (TAM) by using one fundamental stream which focuses on individual acceptance of technology by using intention as dependent variable (Compeau and Higgins, 1995; Davis et al 1989). The unified theory of acceptance and use of technology (UTAUT) (Venkatesh et al, 
2003) is the last generation of technology acceptance theory with seven constructs which appeared to be significant direct determinants of intention and continuous usage (Venkatesh et al, 2003). As the countless of studies done in the field of information technology and adaptation of technology, none of the studies have tried to linked the Venkatesh et al (2003) user theory of acceptance and use of technology (UTAUT) to Malaysian consumers in the context of Call Taxi App. Therefore, this research study will try to explore whether, Venkatesh et al (2003) theory can be applied and it can fit the Malaysian context of study.

2.3 Critical Review of Venkatesh et al., (2003) user theory of acceptance and use of technology (UTAUT)

Researchers and practitioners have conducted technology acceptance studies for over two decades now. They have used various theories and models to carry out these studies in different context. The user theory of acceptance and use of technology (UTAUT) has been a theory that was used by several researchers and practitioners because the model unified eight theories and models which include theory of reasoned action (TRA) (Fishbein and Ajzen, 1975); social cognitive theory (SCT) (Bandura, 1986), model of PC utilization (Thompson et al, 1991), technology acceptance model (TAM) (Davis et al, 1992), theory of planned behaviour (TPB) (Ajzen, 1991) and also combined TAM and TPB (C-TAM-TPB) (Taylor and Todd, 1995). All these theories and model have contributed to the development of UTAUT (Venkatesh et al, 2003), which makes the UTAUT one of the latest theory in the field of information system and adaptation of technology. Chronological foundation of Venkatesh et al (2003) theory of acceptance and use of technology (UTAUT): As the UTAUT explains a particular user intention of adopting an information technology and use of technology (Venkatesh et al, 2003), it was firstly developed from the theory of reasoned action (TRA) (Fishbein and Ajzen, 1975) which is the foundation of technology acceptance model (TAM) (Davis et al, 1992) and lead to UTAUT (Venkatesh el al, 2003).

Fishbein and Ajzen (1975) Theory of reasoned action (TRA) is one of the three classic persuasion models of psychology, developed by Martin Fishbein and Icek Ajzen in 1967, the theory aims to predict the behavior of person to commit certain actions. The theory had the capability of estimating the prediction of an individual to perform a behavior based on an individual's attitudinal and normative beliefs (Southey, 2011). Though, the theory was criticized for lack of predicting an individual behavior (Werner, 2004), because a person behavior is not only predicted by attitude, subjective norms and perceived behavioral control (Ajzen, 1991), there are other factors that control them too due to this criticism TAM (Davis, 1989) was created for predicting user behavior in the field of information technology. Davis (1989) Technology Acceptance Model (TAM) is an information system theory that model user intention to accepted and use technology, Davis (1986) proposed that there are two factors that can impact user intention to use technology which are perceived usefulness and perceived ease of use. However, Venkatesh and Davis (2000) criticized the model for not predicting external factors that impact user adaptation of technology and use of it such as social influence and facilitating condition (Venkatesh and Balla, 2008) from this issue the 


\section{Macrothink Institute ${ }^{\text {TM }}$}

Venkatesh et al (2003) developed the user theory of acceptance and use of technology.

As a result of past theories and model in the field of information system Venkatesh et al (2003) ATAUT was created. The model illustrates the relationship between exogenous variables, endogenous variables and moderators. Thus, the theory has four exogenous variables: Effort Expectancy, Performance Expectancy, Social Influence and Facilitating Condition. Two endogenous variables: Behavioral Intention and Use Behavior. Four Moderators: Age, Gender, Experience and Voluntariness of Use.

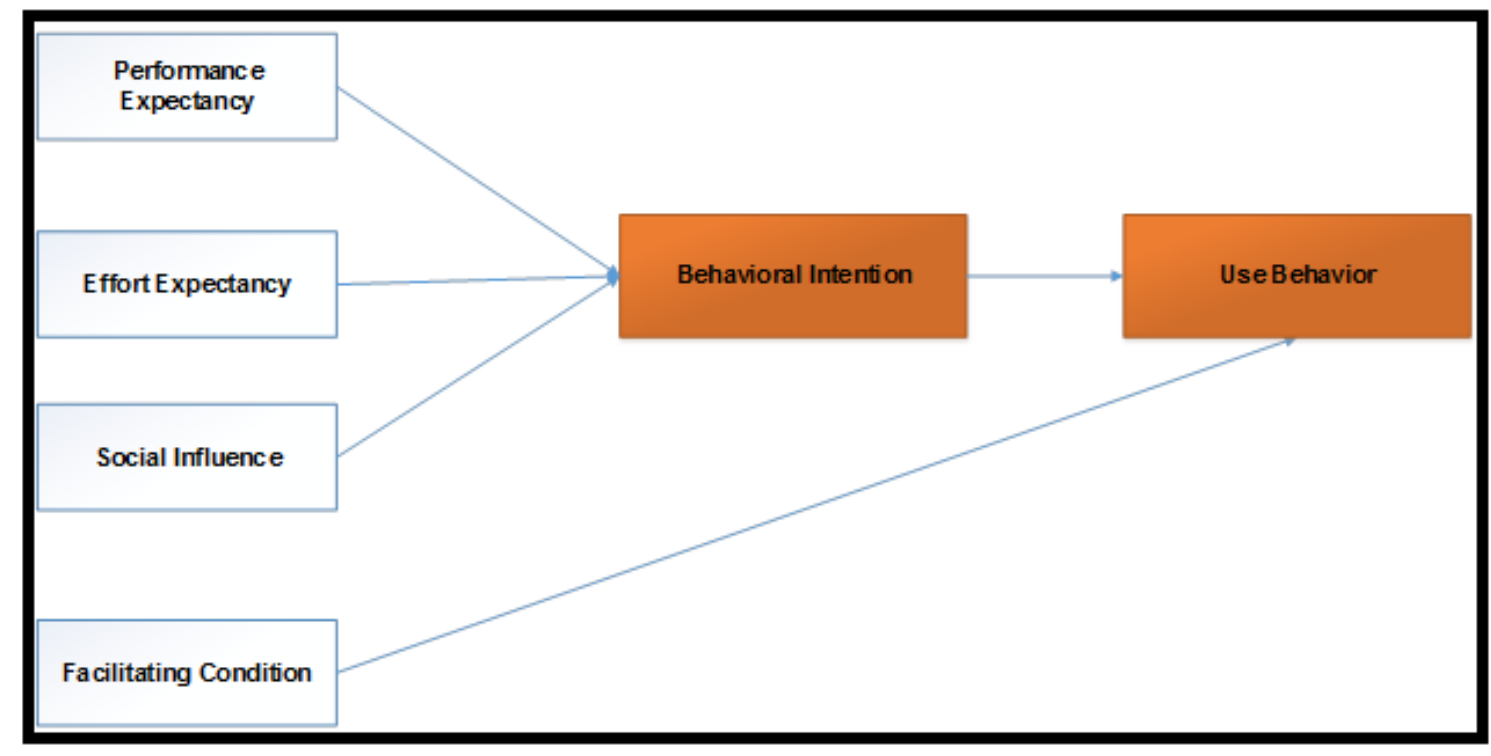

Figure 1. Proposed Conceptual Framework

\subsection{Exogenous Variables}

Performance Expectancy is the degree to which an individual believes that utilizing a particular system will benefit him in term of service (Venkatesh et al, 2003). It is hypothesized to moderate the impact on behavioral intention by moderators which are gender and age (Alqudah, 2015). Verhoeven et al, (2010) applied UTAUT study computer frequency in 741 university Freshmen in Belgium and found that UTAUT was useful in explaining varying frequencies of computer use and differences in information and communication technology skills in secondary school and in the university.

H1: Performance Expectancy has a significant impact of behavioral intention to use taxi call app among Malaysian consumers.

Effort Expectancy is the degree of ease associated with use of the system (Venkatesh et al, 2003). It is hypothesized to moderate the impact on behavioral intention by moderators which are gender, age and experience (Alqudah, 2015). Koivumäki et al(2015) applied UTAUT to study the perception of 243 individuals in northern Finland toward mobile service and technology and found that time spent using the devices did not affect consumer perception but familiarity with devices and user skills did have an impact. 
H2: Effort Expectancy has a significant impact on behavioral intention of use taxi call app among Malaysian consumers.

Social Influence is the degree to which an individual perceives that important other people believes he or she should use the system (Venkatesh et al, 2003). It is hypothesized to moderate the impact on behavioral intention by moderators which are gender, age and experience (Alqudah, 2015). Eckhardt et al (2009) applied study on social influence of workplace referent groups (superiors and colleagues) on intention to adopt technology in 152 German companies and found significant impact of social influence from workplace referent on information technology adoption.

H3: Social Influence has a significant impact on behavioral intention of taxi call app among Malaysian consumers.

Facilitating Condition is the degree to which an individual believes that an organizational and technical infrastructure exists to support use of the system (Venkatesh et al, 2003). It is hypothesized to moderate the impact on behavioral intention by moderators which are age and experience (Alqudah, 2015). Curtis et al (2010) applied UTAUT to the adoption of social media by 409 United States non-profit organizations. UTAUT had not been previously applied to the use of social media in public relations. They found that organizations with defined public relations departments are more likely to adopt social media technologies and use them to achieve their organizational goals.

H4: Facilitating Condition has a significant impact on use behavior on taxi call app among Malaysian consumers.

\subsection{Endogenous Variables}

Behavioral Intention is defined as person's perceived likelihood or subjective probability that she or he will engage in a given behavior (Committee on communication of behavior change in the $21^{\text {st }}$ century, 2002). It is behavior-specific and operationalized by direct questions such as "I intend to [behavior]," and is distinct from similar concepts such as desire and self-prediction (Armitage \& Conner, 2001). Ajzen (1991) argued that it reflects how hard a person is willing to try, and how motivated he or she is, to perform the behavior.

Use Behavior is defined as person's complete acceptance to perform a certain behavior and promise to continue performing the same before (Committee on communication of behavior change in the $21^{\text {st }}$ century, 2002). Though use behavior can be impacted a person Behavioral intention which means basically when he or she intends, he or she will act.

H5: Behavioral Intention has a significant impact on use behavior of taxi call app among Malaysian consumers. 


\section{Research Methodology}

\subsection{Research Design}

Considerably, the research philosophy used in this research is positivism research adhere to the view that only factual knowledge is observed which the measurement is trustworthy (Colins, 2010). The reason of choosing positivism research philosophy in this research study is because it is limited to data collection and interpretation of the data through objective approach and the research findings are usually observable and quantifiable (Easterby-Smith et al, 2008). The function of a research design is to ensure that evidence obtained enables the researcher to effectively address the research problem logically and as unambiguously as possible (DeVaus, 2001). The research study follows exploratory research design which explicitly helps the research to attain its objectives. Scientists, scholars and authors have used exploratory research design in order to determine the nature of problem nevertheless it does not give conclusive answer or findings (Sanders et al, 2009). Exploratory research design helps the researcher to find out solution in order to have a better understanding of the problem in this research study (Brown, 2006). The aim of the study is to find out whether taxi hailing companies are failing to adapt the unified technology acceptance model and use of technology in their company or whether the model is fit for taxi hailing app in Malaysia.

A research method is a technique manufactured by a researcher which has for objectives to lay out the process follow by the researcher in order to answer the research questions (Trochim, 2006). However, there are three types of research methods which are qualitative, quantitative and mix research method, though in this study, the researcher is going to use quantitative research study. Quantitative research method emphasizes on objective measurements with statistical, mathematical or numerical analysis of data collected through pools, questionnaires and surveys (Babbie, 2010). Quantitative research method focuses on its main objective of gathering numerical data ad generalizing it across groups of people to explain a particular phenomenon in the research study (Singh, 2007). Data collection method is a process of gathering and measuring information on targeted variables in an established systematic fashion which then enables one to answer relevant questions and evaluates outcomes (Bernard et al, 2009).

\subsection{Data Collection Method}

In this research study, primary data is collected by researchers mostly through online survey questionnaire, the reason why online survey questionnaire will be utilized for the data collection of the study is because it is reachable, more accurate, convenience for respondents in this era of technology, it is also time saving and cost efficient for the researchers. The language of the survey will be English language as it is the second language in Malaysia and can be used by both international and local people in the country.

Therefore, the questionnaire structure will be composed of three main parts, the first part is more concerned about the demographic data (gender, age, race and type of taxi hailing companies), the second part is about the exogenous variables which made of three constructs 
for each variable (four exogenous variables = twelve constructs). The endogenous variables which is about three constructs for each variable (two endogenous variables = six constructs). The questionnaire used follows a liker scale of 1 to 5 points.

\subsection{Sampling Method, Sample Size, Targeted Population \& Sample Adequacy}

Sampling technique in this study is more concerned with the selection of a subset of target audience from within a statistical population in order estimate characteristics of the whole population (Chamber and Skinner, 2003). The sampling method that is used in this study is the convenience sampling technique which is a non-probability sampling method that is made up of people whom are easy to research (Etikan, 2016). The target population of this research study is international and local customer in Malaysia, who makes use of taxi hailing app in order to satisfy their transportation needs. Several ethical issues will be coming along the way of this research study from the primary data collection method which is mainly data cooking and data manipulation in order to answer the research objectives of this study.

Table 1. KMO and Bartlett’s Test for Sample Adequacy

\begin{tabular}{|lllc|}
\hline Kaiser-Meyer-Olkin & Measure of Sampling & Adequacy & 0.966 \\
\hline Bartlett’s & Test of Sphericity Approx. & Chi-Square & 3814.008 \\
Df 153 & & & \\
Sig 0.00 & & & \\
\hline
\end{tabular}

According to the table 3 for sample adequacy test, there is an excellent sample adequacy for the Kaiser-Meyer-Olkin (KMO) test which is greater than 0.9 (Research Study KMO=0.966) with a significance for the Bartlett's Test of Sphericity with a P-value lesser than $0.05>0.000$ (Shuttleworth, 2008).

\subsection{Reliability of the Measurement Items}

Table 2. Reliability Test

\begin{tabular}{|l|c|c|}
\hline Construct & Cronbach's Alpha & Number of Items \\
\hline Performance Expectancy & 0.935 & 3 \\
Effort Expectancy & 0.936 & 3 \\
Social Influence & 0.771 & 3 \\
Facilitating Condition & 0.843 & 3 \\
Behavioural Intention & 0.903 & 3 \\
Use Behaviour & 0.919 & 3 \\
\hline
\end{tabular}

According to George and Mallery (2003), an excellent Cronbach's Alpha for reliability test is measured above 0.9 nevertheless a good Cronbach's Alpha for reliability test is measured $(0.7$ to 0.9). However, this research study dataset reliability test for the Cronbach's Alpha is ranged (0.771 to 0.936$)$ which means that the research study has a reliable data. 


\subsection{Data Analysis Plan}

Within the academic literature of many fields, Rigdon (1998) remarks, structural equation modelling (SEM) has taken up a prominent role. Whenever researchers deal with relations between constructs such as satisfaction, role ambiguity, or attitude, SEM is likely to be the methodology of choice. Since SEM is designed for working with multiple related equations simultaneously, it offers a number of advantages over some more familiar methods and therefore provides a general framework for linear modelling. SEM allows great flexibility on how the equations are specified (Suhr, 2000). The development of an evocative graphical language has accompanied the development of SEM as a statistical method. Due to this language, complex relationships can be presented in a convenient and powerful way to others not familiar with SEM. However, this research study applies confirmatory factors analysis (CFA) which is a statistical technique used to verify the factor structure of a set of observed variables for the purpose of understanding whether or not the model is fit to undertake a structural equation modelling (SEM) and the structural equation modelling (SEM) is used in this study for the purpose of testing the research hypothesis and the mediating effect.

Table 3. Demographic Classification

\begin{tabular}{|l|l|l|l|}
\hline Criteria & Category & Number & Percentage \\
\hline Gender & Male & 122 & $61 \%$ \\
& Female & 79 & $39 \%$ \\
\hline \multirow{5}{*}{ Age Group } & $18-25$ & 78 & $39 \%$ \\
& $26-30$ & 64 & $32 \%$ \\
& $31-35$ & 34 & $17 \%$ \\
& $36-40$ & 6 & $3 \%$ \\
& $41-45$ & 9 & $4 \%$ \\
& Above 45 & 10 & $5 \%$ \\
\hline \multirow{5}{*}{ Experience } & 1 year & 85 & $43 \%$ \\
& 2 years & 56 & $28 \%$ \\
& 3 years & 32 & $16 \%$ \\
& 4 years & 4 & $2 \%$ \\
& 5 years & 6 & $3 \%$ \\
& Above 5 years & 18 & $8 \%$ \\
\hline \multirow{5}{*}{ Type of Taxi Hailing App } & Yes & 167 & $84 \%$ \\
& No & 12 & $6 \%$ \\
& Mber & 21 & $10 \%$ \\
\hline & Both & 66 & $33 \%$ \\
& GrabCAR & 35 & $17 \%$ \\
& Student & 99 & $50 \%$ \\
\hline & Housewife & 108 & $54 \%$ \\
& Private Company Employee & 70 & $35 \%$ \\
\hline
\end{tabular}




\begin{tabular}{|l|l|l|l|}
\hline & $\begin{array}{l}\text { Public Sector Employee } \\
\text { Others }\end{array}$ & $\begin{array}{l}7 \\
10\end{array}$ & $\begin{array}{l}3.5 \% \\
5 \%\end{array}$ \\
\hline
\end{tabular}

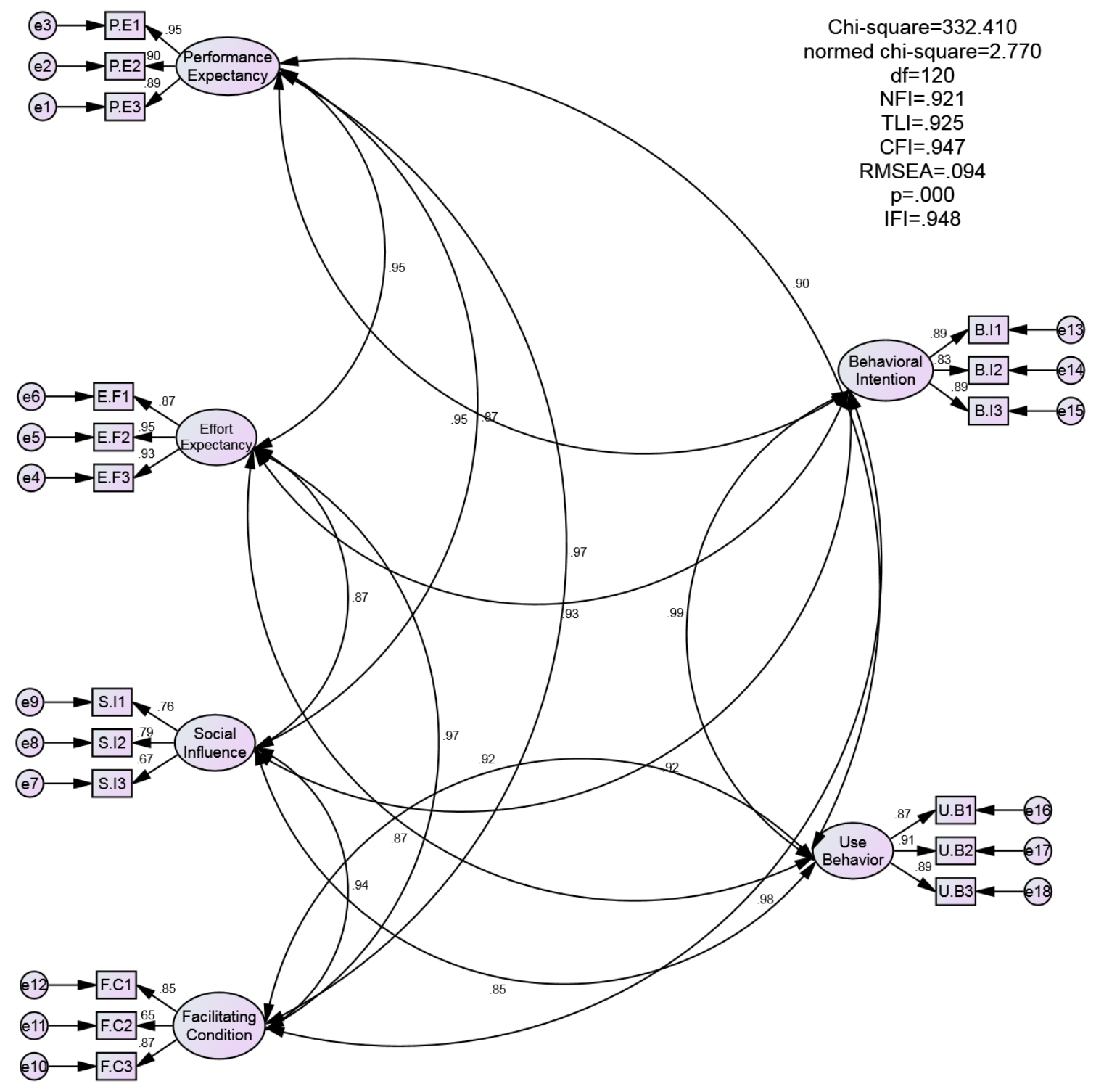

Figure 2. Confirmatory Factor Analysis (CFA)

\section{Findings and Analysis}

\subsection{Demographic Classification}

With convenience sampling technique, table 1 shows and demonstrates the demographic classification of the data collected through survey questionnaire. For the Gender category, 122 males and 79 females responded, the age group category 79 (18-25), 64 (26-30), 34 (31-35), 6 (36-40), 9 (41-45) and above 45 years old 10 responded; for the experience 1 year (85), 2 years (56), 3 years (32), 4 years (4), 5 years (6) and above 5 years 18 people 
responded; for voluntariness 167 people said yes to voluntarily used taxi hailing app, 12 people said no and 21 people expressed the dilemma maybe; among the people surveyed in Malaysia 33\% of them used GrabCar, 17\% of them used Uber and the remaining 50\% used both taxi hailing app from different professions 108 students, 5 housewives, 70 private company employees, 7 public sector employees and others 10 people not mentioning their profession.

\subsection{Confirmatory Factor Analysis (CFA)}

Confirmatory factor analysis (CFA) helps to verify how well latent constructs represent the study before modelling the inter-relationship of a structural model (Brown, 2006). It helps researcher by giving understandable means for validating the measurement model of latent constructs (DiStefano and Hess, 2005). However, there are three steps of validating the latent constructs used in a research study which are construct validity, divergent validity and discriminant validity (Afthanorhan and Ahmed, 2013).

\subsection{Construct Validity}

Construct validity is a validity test which tries to demonstrate whether the fitness indexes from the confirmatory factor analysis (CFA) are achieved or reached the required level in order to undertake the structural equation modelling (SEM) (Hair et al, 2010; Holmes-smith, 2006). Therefore, the choice of indexes is noted in table 4.

Table 4. Literature Support of Respective Fitness Index

\begin{tabular}{|l|l|l|l|}
\hline $\begin{array}{l}\text { Name of } \\
\text { Category }\end{array}$ & $\begin{array}{l}\text { Name } \\
\text { Indexes }\end{array}$ & Level of Acceptance & Citations \\
\hline \multirow{2}{*}{ Absolute fit } & Chi-square & P-value $>0.05$ & Wheaton et al. (1977) \\
\cline { 2 - 4 } & RMSEA & RMSEA $<0.08$ & $\begin{array}{l}\text { Browne and Cudeck } \\
(1993)\end{array}$ \\
\hline \multirow{3}{*}{ Incremental fit } & CFI & CFI $>0.09$ & Bentler (1990) \\
\cline { 2 - 4 } & TLI & TLI $>0.09$ & Bentler and Bonett (1980) \\
\cline { 2 - 4 } & IFI & IFI $>0.09$ & Bollen (1989b) \\
\cline { 2 - 4 } Parsimonious fit & NFI & NFI $>0.09$ & $\begin{array}{l}\text { Marsh and Hocevar } \\
(1985)\end{array}$ \\
\hline
\end{tabular}

*** One could ignore the absolute fit index of minimum discrepancy chi-square if the sample size obtained for the research study is greater than 200 (Hair et al, 1996; Joreskog and Sorbom, 1996).

Table 5 in this research study is going to show the research fitness indexes found and their level of achievement. 
Table 5. Construct Validity Fitness Indexes

\begin{tabular}{|l|l|l|l|}
\hline $\begin{array}{l}\text { Name of } \\
\text { Category }\end{array}$ & $\begin{array}{l}\text { Name of } \\
\text { Indexes }\end{array}$ & $\begin{array}{l}\text { Level } \\
\text { Acceptance }\end{array}$ & Citations \\
\hline Absolute fit & Chi-square & P-value $=0.00$ & $\begin{array}{l}\text { Level of acceptance not achieved } \\
\text { due to sample size. }\end{array}$ \\
\cline { 2 - 4 } & RMSEA & RMSEA $=0.94$ & $\begin{array}{l}\text { Level of acceptance not achieved } \\
\text { due to sample size. }\end{array}$ \\
\hline \multirow{3}{*}{ Incremental fit } & CFI & CFI $=0.947$ & Level of acceptance achieved \\
\cline { 2 - 4 } & TLI & TLI $=0.925$ & Level of acceptance achieved \\
\cline { 2 - 4 } & IFI & IFI $=0.948$ & Level of acceptance achieved \\
\cline { 2 - 4 } & NFI & NFI $=0.921$ & Level of acceptance achieved \\
\hline Parsimonious fit & Chi-square/df & $\begin{array}{l}\text { Normed Chi-square } \\
=2.7\end{array}$ & Level of acceptance achieved \\
\hline & & \multicolumn{2}{|l}{} \\
\hline
\end{tabular}

According to Hair et al (2010) \& Holmes-smith (2006); the comparative fit index (CFI), incremental fit index (IFI), normed fit index (NFI), tucker Lewis index (TLI) and normed chi-square have achieved the statistical level of acceptance. Nevertheless, the chi-square and the root mean square error of approximation (RMSEA) do not achieve the level of acceptance due to sample size (Ullman, 2001).

\subsection{Divergent Validity}

Divergent validity is done with the factors loading for the purpose of validated the reliability of each construct that exist in the confirmatory factor analysis (CFA) before undertaking the structural equation modelling (SEM).

Table 6. Divergent Validity Measurement

\section{Construct PE EF SI FC}

PE1 0.95

PE2 0.90

PE3 0.89

$\begin{array}{ll}\text { EF1 } & 0.87\end{array}$

$\begin{array}{ll}\text { EF2 } & 0.95\end{array}$

$\begin{array}{ll}\text { EF3 } & 0.93\end{array}$

$\begin{array}{ll}\text { SI1 } & 0.76\end{array}$

$\begin{array}{ll}\text { SI2 } & 0.79\end{array}$ 


\begin{tabular}{ll}
\hline SI3 & 0.67
\end{tabular}

$\begin{array}{ll}\text { FC1 } & 0.85 \\ \text { FC2 } & 0.65 \\ \text { FC3 } & 0.87\end{array}$

$\mathrm{BI} 1$

BI2

$\mathrm{BI} 3$

0.89

UB1

UB2

UB3

The factor loading of each construct in this research study is actually starting from 0.65 to 0.95. However, according to Awang (2014), for an established construct, the factor loading for every item should start must be higher than 0.6 to achieve the divergent validity requirement. The construct reliability is done by the Cronbach's alpha in IBM SPSS Statistics 20 in order to demonstrate the liability of each construct, thus according to George and Mallery (2003), an excellent Cronbach's Alpha for reliability test is measured above 0.9 nevertheless a good Cronbach's Alpha for reliability test is measured (0.7 to 0.9 ).

\subsection{Discriminant Validity}

Discriminant validity has for objective to show the uniqueness of the constructs in the model and captures some phenomenon other measures do not (MacQueen, 1967). CFA has two practical manners to calculate and test a discriminant validity of a model first by correlation between constructs and second by comparison of AVE (Macqueen, 1967). Understandably, the most used technique for discriminant validity is the correlation between constructs for purpose of finding the linear relationship.

Table 7. Construct Variance

\begin{tabular}{|l|lc|}
\hline & P.E E.F S.I F.C B.I U.B \\
\hline P.E & 1 \\
E.F & 0.953 & 1 \\
\hline
\end{tabular}




\begin{tabular}{|l|llll|}
\hline S.I & 0.870 & 0.865 & 1 & \\
F.C & 0.973 & 0.9710 .9381 & & \\
B.I & 0.953 & 0.9260 .9230 .9531 & & \\
U.B & 0.901 & 0.8710 .854 & 0.917 & 0.917 \\
\hline
\end{tabular}

In essence, it is the same as specifying that the items making up two constructs could just as well make up only one construct. If the fit of the two construct model is significantly different from that of the one-construct model, then the discriminant validity is supported even though there is high correlation as high as 0.9. A general rule of thumb is that correlations close to or beyond 0.7 or -0.7 are considered to be strong correlation. Therefore in this research study there is a strong positive upward correlation among the listed constructs.

\subsection{Structural Equation Modeling (SEM)}

It is a family of statistical models that has for objectives to explain the relationships among multiple variables or the extension of exploratory findings (Hoyle, 1995). In doing so, it examines the interrelationships expressed in a series of equations (Rigdon, 1998). 


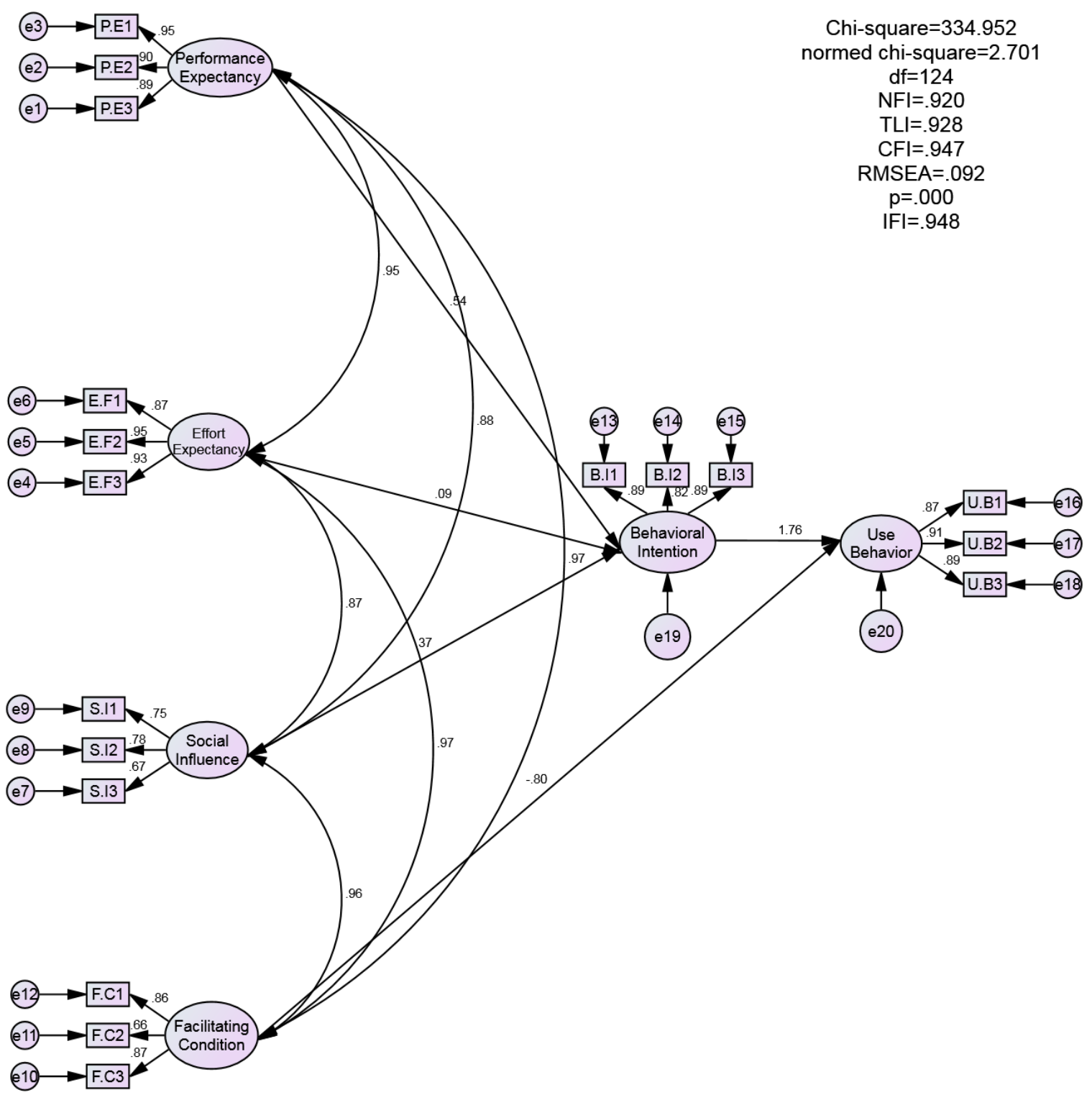

Figure 3. Structural Equation Modeling (SEM)

\subsection{Measurement Model Comparison}

The process of comparing the structural equation modeling (SEM) and confirmatory factor analysis (CFA) parameters built by the researcher has for objective to cross-validate the two models upon measurement to evaluate the differences between them before the path analysis result.

Table 8. Comparison of Factor Loadings

\begin{tabular}{|l|l|l|}
\hline Construct & Structural Equation Modeling & Confirmatory Factor Analysis \\
\hline P.E1 & 0.95 & 0.95 \\
P.E2 & 0.90 & 0.90 \\
P.E3 & 0.89 & 0.89 \\
E.F1 & 0.87 & 0.87 \\
\hline
\end{tabular}




\begin{tabular}{|l|l|l|}
\hline E.F2 & 0.95 & 0.95 \\
E.F3 & 0.93 & 0.93 \\
S.I1 & 0.75 & 0.76 \\
S.I2 & 0.78 & 0.79 \\
S.I3 & 0.67 & 0.67 \\
F.C1 & 0.86 & 0.85 \\
F.C2 & 0.66 & 0.65 \\
F.C3 & 0.87 & 0.87 \\
B.I1 & 0.89 & 0.89 \\
B.I2 & 0.82 & 0.83 \\
B.I3 & 0.89 & 0.89 \\
U.B1 & 0.87 & 0.87 \\
U.B2 & 0.91 & 0.91 \\
U.B3 & 0.89 & 0.89 \\
\hline
\end{tabular}

The comparison of factor loadings demonstrate that there is not much difference between the SEM and CFA factor loadings, thus the path analysis can be undertaken in order to test the research hypothesis.

Table 9. Comparison of Fitness Indexes

\begin{tabular}{|c|c|c|}
\hline FITNESS INDICES & Structural Equation Modelling & Confirmatory Factor Analysis \\
\hline NFI & 0.920 & 0.921 \\
IFI & 0.948 & 0.948 \\
TLI & 0.928 & 0.925 \\
CFI & 0.947 & 0.947 \\
\hline Normed Chi-square & 2.701 & 2.701 \\
\hline
\end{tabular}

The comparison of fit indices of SEM and CFA show that the path analysis can be undertaken because there is not much differences between them, only slightly differences of NFI $(\mathrm{SEM}=0.920 ; \mathrm{CFA}=0.921)$ and TLI $(\mathrm{SEM}=0.928$; $\mathrm{CFA}=0.925)$.

\subsection{Correlation Analysis}

Table 10. Correlation between Exogenous Constructs

\begin{tabular}{|l|c|c|}
\hline Constructs Correlation & SEM & CFA \\
\hline Performance Expectancy $<-->$ Effort Expectancy & 0.954 & 0.953 \\
\hline
\end{tabular}


Effort Expectancy <--> Social Influence

Facilitating Condition ---> Effort Expectancy

Facilitating Condition <--> Social Influence

Performance Expectancy <--> Social Influence

Facilitating Condition <--> Performance Expectancy
0.872

0.966

0.956

0.938

0.876

0.870

0.974

0.973

\subsection{Path Analysis}

Understandably, the path diagram (Fig 3) measurement of hypothetical testing will demonstrate the real findings of the research objectives in table 11 with P-value and the estimate which the statistical test value that is going to understand the casual relationship between the constructs.

Table 11. Path Analysis Result

\begin{tabular}{|c|c|c|c|c|c|c|}
\hline & & & Estimate & S.E. & C.R. & P-value \\
\hline $\begin{array}{l}\text { Behavioral } \\
\text { Intention }\end{array}$ & $<---$ & $\begin{array}{l}\text { Performance } \\
\text { Expectancy }\end{array}$ & .550 & .156 & 3.531 & $* * *$ \\
\hline $\begin{array}{l}\text { Behavioral } \\
\text { Intention }\end{array}$ & $<---$ & Effort Expectancy & .092 & .138 & .665 & .506 \\
\hline $\begin{array}{l}\text { Behavioral } \\
\text { Intention }\end{array}$ & $<---$ & Social Influence & .531 & .138 & 3.860 & $* * *$ \\
\hline Use Behavior & $<---$ & Behavioral Intention & 1.700 & .475 & 3.580 & $* * *$ \\
\hline Use Behavior & $<---$ & Facilitating Condition & -.836 & .501 & -1.669 & .095 \\
\hline
\end{tabular}

\subsection{Discussion of the First Findings}

Comprehensively, in table 11, it has been found that some endogenous constructs have significant impact on exogenous constructs with positive estimates.

Performance expectancy is defined as the degree to which a user believes that when utilizing or adapting a system can aid him or her to achieve their ultimate goal, it is used in Davis et al (1989) technology acceptance model (TAM) as perceived usefulness and also as an extrinsic motivation which can be perceived as value (Thompson et al, 1991). It has been known in Venkatesh et al (2003) Unified theory of acceptance and use of technology (UTAUT) as a strongest predictor of behavioral intention and use behavior. However, in this research study performance expectancy has a positive significant impact on behavioral intention of taxi hailing app user in Malaysia with an estimate value of 0.555 and a P-value (sig=0.000< 0.05 ), thus the first hypothesis is accepted and supported by the study of Verhoeven et al, (2010) applied UTAUT study computer frequency in 741 university Freshmen in Belgium and found that UTAUT was useful in explaining varying frequencies of computer use and differences in 
information and communication technology skills in secondary school and in the university.

Effort expectancy is defined as the degree of ease or easiness associated to a particular system that a user can utilize or adopt in order to accept the system (Davis et al, 1989; Moore and Benbasat, 1991; Plouffe et al, 2001; Thompson et al, 1991). Therefore, according to this research study hypothesis the effort expectancy construct within the UTAUT is significant nevertheless this research study found the contraire statistical not significant with an estimate of 0.092 and a p-value (sig=0.506 >0.05), hence, according to Agarwal \& Prasad, (1997); Thompson et al, (1994); consistent previous research studies have found effort expectancy does not significant impact on behavioral intention because of sustained usage and over periods of extension. Applying to this research study effort expectancy does not have significant impact on Malaysian taxi hailing app users’ behavioral intention.

Social influence as a very important construct in social science which has been used mostly social scientists and researchers found this construct mostly significant and important predictor of behavioral intention because it is the level to which an individual perceives that important persons in his or her circle believe that he or she should use the system (Venkatesh and Davis, 2000; Thompson et al, 1991). Moreover, in this research study, social influence has positive significant impact on behavioral intention of Malaysian taxi hailing app user with an estimate of 0.531 and a p-value ( $\operatorname{sig}=0.00<0.05)$, this research hypothesis is supported by the study of Eckhardt et al (2009) applied study on social influence of workplace referent groups (superiors and colleagues) on intention to adopt technology in 152 German companies and found significant impact of social influence from workplace referent on information technology adoption.

According to Venkatesh et al (2003) theory, facilitating condition should have direct impact on use behavior because it is a level to which a user believes that there is a real technical infrastructure established in order to support the use of the system, known as a core component of perceived behavioral control (Taylor and Todd, 1995; Venkatesh, 2000). Understandably this hypothesis in the research study is not supported statistically with an estimate of -0.836 and a p-value (sig=0.092>0.05).

\subsection{Mediating Effect}

Mediating effect is created when a third construct intervenes between two other related constructs in a structural equation model for the purpose of finding the indirect effect which involve the sequence of relationships with at least one intervening construct implicated. Therefore, in this research study behavioral intention is the mediator between use behavior and (performance expectancy, effort expectancy and social influence). Though, behavioral intention has a positive impact on use behavior of Malaysian taxi hailing app user with a high estimate of 1.700 and a $p$-value (sig=0.000<0.05). This demonstrates theoretically that performance expectancy, effort expectancy and social influence have indirect effect on use behavior through the mediator behavioral intention. Hence, the hypothesis is accepted. 


\begin{tabular}{|l|l|l|}
\hline Hypothesis & $\begin{array}{l}\text { P-valu } \\
\text { e }\end{array}$ & Conclusion \\
\hline $\begin{array}{l}\text { H1: Performance Expectancy has a significant impact of } \\
\text { behavioral intention to use taxi hailing app among Malaysian } \\
\text { User. }\end{array}$ & 0.000 & Accepted \\
$\begin{array}{l}\text { H2: Effort Expectancy has a significant impact of behavioral } \\
\text { intention to use taxi hailing app among Malaysian User. }\end{array}$ & 0.000 \\
$\begin{array}{l}\text { H3: Social Influence has a significant impact on behavioral } \\
\text { intention to use taxi hailing app among Malaysian User. }\end{array}$ & Accepted \\
$\begin{array}{l}\text { H4: Facilitating condition has a significant impact on use } \\
\text { behavior of taxi hailing app among Malaysian User. } \\
\text { H5: Behavioral intention has a significant impact on use behavior } \\
\text { of taxi hailing app among Malaysian User. }\end{array}$ & 0.002 & Rejected \\
\hline
\end{tabular}

\section{Conclusion and Recommendation}

According to Davis (1981) technology acceptance model (TAM) which has been decidedly predicting the behavioral intention of an individual in the field of information system (IS) which lead to the unified theory of acceptance and use of technology of Venkatesh et al (2003). The researcher has tested the theory of Venkatesh et al (2003) without moderator by applying it to taxi hailing app among users in Malaysia. Performance expectancy, being one of the most important construct of predicting human behaviour because it is the believe that an individual has when utilizing a particular system will benefit him or her in term of service (Venkatesh et al, 2003), the construct has a significant impact on behavioral intention with a p-value of 0.000; also followed by social influence which also have a significant impact on behavioral intention with a p-value of 0.000 ; comprehensively, several researchers have studied and found out that social influence is one of the main predictors of human behavior. Effort expectancy does not have influence of taxi hailing app user behavioral intention in Malaysia, moreover, facilitating condition does not have significant on user continuous use behavior of taxi hailing app in Malaysia.

For scholars and researchers, understandably this research study open the gate way of the application of Venkatesh et al (2003) unified theory of acceptance and use of technology (UTAUT) on information system (IS) apps that had been recently created. It helps scholars and researchers to understand if the theory constructs have been accepted without by information system users and also how it can be extended or criticized for its use. For managers, taxi hailing app companies had been very lucrative entities that have attracted millions of users around the world especially in Malaysia. This research can help the managers of those companies plan strategically the ways they can market their service by knowing what the significant factors to take into consideration are.

\section{References}

Ajzen, I. (1991). The theory of planned behavior. Organizational Behavior and Human 
Decision Processes, 50, 179-211.

Alqudah, A. (2015). Unified Theory of Acceptance and Use of Technology (UTAUT). $\begin{array}{llll}\text { Retrieved Jun, } & 18 & \text { 2017, from }\end{array}$ https://www.linkedin.com/pulse/unified-theory-acceptance-use-technology-utaut-ayman-alqu dah

Armitage, C. and Conner, M. (2001). Efficacy of the Theory of Planned Behaviour: a meta-analytic review. US national Library of Medicine, National Institute of Health, 40, 471-99.

Awang, Z. (2014). Research Methodology and Data Analysis (2nd ed.). Universiti Teknologi Mara, UiTM Press.

BABBIE, E. (2010). The practice of social research. Belmont, CA; : Wadsworth.

Bandura, A. (1986). Social foundations of thought and action: A social cognitive theory. Englewood Cliffs, N.J.: Prentice-Hall.

Bentler, P. M. (1990). Comparative Fit Indexes in Structural Models. Psychological Bulletin, 107(2), 238-46.

Bentler, P. M., \& Bonnet, D. C. (1980). Significance Tests and Goodness of Fit in the Analysis of Covariance Structures. Psychological Bulletin, 88(3), 588-606.

Bernard, H., Ruseell, \& Gerry, W. R. (2009). Analyzing Qualitative Data: Systematic Approaches, Thousand Oaks, Calif.: Sage, 2009.

Bollen, K. A. (1990). Overall Fit in Covariance Structure Models: Two Types of Sample Size Effects. Psychological Bulletin, 107(2), 256-59.

Brown, R. B. (2006). Doing Your Dissertation in Business and Management: The Reality of Research and Writing” Sage Publications, p.43

Browne, M. W., \& Cudeck, R. (1989). Single sample cross-validation indices for covariance structures. Multivariate Behavioral Research, 24, 445-455.

Byrne, B. M. (2001). Structural Equation Modeling With AMOS: Basics Concepts, Applications and Programming. Mahwah, NJ: Lawrence Erlbaum Associates.

Chambers, R., \& Skinner, C. (2003). Analysis of Survey Data. University of Southampton, UK. Retrieved Jun 18, 2017, from http://bbu.yolasite.com/resources/analysis_survey_data.pdf

Chan, J., Chang, V., Lau, W., Law, L., \& Lei, C. (2016). Taxi App Market Analysis in Hong Kong. Journal of Economics, Business and Management. Retrieved Jun 18, 2017, from http://www.joebm.com/vol4/397-A001.pdf

Chew, J. (2016). NDR 2016: EMBRACE CHANGES WITH UBER AND GRAB CAR. [online] CARROBLOG. $\quad$ Retrieved Jun 18, 2017, from 
$<$ https://carro.sg/blog/ndr-2016-levelling-playing-field-for-taxis-uber-grab/

Collins, H. (2010). Creative research: the theory and practice of research for the creative industries. Lausanne: AVA Publishing SA.

Committee on Communication for Behavior Change in the 21st Century (2002). Speaking of Health: Assessing Health Communication Strategies for Diverse Populations. Washington, DC: National Academies Press.

Compeau, D., Higgins, C., \& Huff, S. (1995). Social Cognitive theory and individual reactions to computing technology" A longitudinal study. MIS Quarterly, 23(2), 145-158.

Curtis, L., Edwards, C., Fraser, K. L., Gudelsky, S., Holmquist, J., Thornton, K., \& Sweetser, K. D. (2010). Adoption of social media for public relations by nonprofit organizations. Public Relations Review, 36, 90-92.

Davis, F. (1989). Perceived usefulness, perceived ease of use, and user acceptance of information technology. MIS Quarterly, 13(3), 319-340.

Davis, F., Bagozzi, R., \& Warshaw, P. (1989). User acceptance of computer technology: A comparison of two theoretical models". Management Science, 35, 982-1003.

De Vaus, D., 2001. What is research design?. SAGE Publication. Retrieved Jun 18, 2017, from http://research.apc.org/images/5/5f/De_Vaus_chapters_1_and_2.pdf

Easterby-Smith, M., Thorpe, R., \& Jackson, P. (2008b). Management Research. London: SAGE.

Eckhardt, A., Laumer, S., \& Weitzel, T. (2009). Who influences whom? Analyzing workplace referents' social influence on IT adoption and non-adoption. Journal of Information Technology, 24(1), 11-24.

Etikan, Ilker (2016). Comparison of Convenience Sampling and Purposive Sampling" (PDF). American Journal of Theoretical and Applied Statistics, 5(1).

Fassou Haba, H., Hassan, Z., \& Dastane, O. (2017). Factors Leading to Consumer Perceived Value of Smartphones and its Impact on Purchase Intention. Global Business and Management Research: An International Journal, 9(1), 42-71.

Fishbein, M., \& Ajzen, I. (1975). Belief, attitude, intention and behavior: An introduction to theory and research. Reading, MA: Addison Wesley.

George, D., \& Mallery, P. (2003). SPSS for Windows step by step: A simple guide and reference. 11.0 update (4th ed.). Boston, MA: Allyn \& Bacon

Hair, J. F., Black, W. C., Babin, B. J., \& Anderson, R. E. (2010). Multivariate Data Analysis (7th ed.). Upper Saddle River, New Jersey: Prentice Hall.

Hair, J., Anderson, R., Tatham, R. L., \& Black, W. C. (1996). Multivariate data analysis with 
readings. Englewood Cliffs: Prentice-Hall.

Harrington, D. (2009). Confirmatory Factor Analysis. New York: Oxford University Press.

Holmes-Smith, P., Coote, L., \& Cunningham, E. (2006). Structural Equation Modeling: From the Fundamentals to Advanced Topics. Melbourne: SREAMS.

Hoyle, R. (1995). The structural equation modeling approach: Basic concepts and fundamental issues. In R. H. Hoyle (Ed.), Structural Equation modeling: Concepts, issues, and applications (pp. 1-15). Thousand Oaks CA: Sage

Joreskog, K. G. , \& Sorbom, D. (1996). LISREL8 User’s reference Guide. SSI. McDonald, R. P. (1989). An index of goodness-of-fit based on noncentrality. Journal of Classifi- cation, 6, 97-103

Kemp, S., (2017). Digital in 2017: Global Overview. Retrieved Jun 18, 2017, from https://wearesocial.com/special-reports/digital-in-2017-global-overview

Keong, W. (2015). Factors Influencing Malaysian Taxi Drivers Behavioral Intention To Adopt Mobile Taxi Application. International Journal of Economics, Commerce and Management, 3(11), pp.1-150. Retrieved Jun 17, 2017, from http://ijecm.co.uk/wp-content/uploads/2015/11/31110.pdf

Kline, P. (2000). The handbook of psychological testing (2nd ed.). London: Routledge, p.13.

Koivumäki, T., Ristola, A., \& Kesti, M. (2015). The perceptions towards mobile services: An empirical analysis of the role of use facilitators. Personal and Ubiquitous Computing, 12(1), 67-75.

Kumar, P., \& Kumar, N. (2016). A Study on Factors Influencing the Consumers in Selection of Cab Services. International Journal of Social Science and Humanities Research, 4(3), 557-561.

LIU, Z. (2017). An Analysis of Technology Acceptance Model Exploring user acceptance and intension of taxi-hailing app in Shanghai. University of Gothenburg. Retrieved Jun 17, 2017, from https://gupea.ub.gu.se/bitstream/2077/38592/1/gupea_2077_38592_1.pdf

MacQueen, J. (1967). Some Methods for classification and Analysis of Multivariate Observations, Proceedings of 5-th Berkeley Symposium on Mathematical Statistics and Probability. Berkeley, University of California Press, 1, 28 1-297.

Marsh, H. W., \& Hocevar, D. (1985). Application of confirmatory factor analysis to the study of self-concept: First- and higher order factor models and their invariance across groups. Psychological Bulletin, 97, 562-582

Nakache, P. and Carter, P. (2015). Mobile Commerce In 2015. Retrieved Jun 17, 2017, from https://techcrunch.com/2015/01/18/mobile-commerce-in-2015/

Peng, L., Wang, H., He, X., Guo, D., \& Lin, Y. (2014). Exploring Factors Affecting the User 
Adoption of Call-taxi App. In: 25th Australasian Conference on Information System. Retrieved Jun 17, 2017, from http://aut.researchgateway.ac.nz/bitstream/handle/10292/8040/acis20140_submission_244.pd f?sequence $=1$

Rajabion, L. (2015). Critical Factors for Adoption of Mobile Commerce Services. International Journal of Business and Social Science, 6(12). Retrieved Jun 17, 2017, from https://ijbssnet.com/journals/Vol_6_No_12_December_2015/2.pdf

Rayle, L., Shaheen, S., Chan, N., Dai, D., \& Cervero, R. (2017). App-Based, On-Demand Ride Services: Comparing Taxi and Ridesourcing Trips and User Characteristics in San Francisco. University of California Transportation Center (UCTC). Retrieved Jun 17, 2017, from https://www.its.dot.gov/itspac/dec2014/ridesourcingwhitepaper_nov2014.pdf

Rigdon, E. E. (1998). Structural equation modeling. In Modern methods for business research, G. A. Marcoulides (editor). Mahwah, NJ: Lawrence Erlbaum Associates, Publishers, 251-294.

Saunders, M., Lewis, P., \& Thornhill, A. (2009). Research Methods for Business Students, 5th edition, Prentice Hall.

Shuttleworth, M. (2008). Descriptive research design - observing a phenomenon. Retrived April 24, 2017 from https://explorable.com/descriptive-research-design

Singh, K. (2007). Quantitative Social Research Methods” SAGE Publications, p.64

Southey, G. (2011). The Theories of Reasoned Action and Planned Behaviour Applied to Business Decisions: A Selective Annotated Bibliography. Journal of New Business Ideas \& Trends, 9(1), pp.43-50. Retrieved Jun 17, 2017, from http://www.jnbit.org/upload/JNBIT_Southey_2011_1.pdf

Suhr, D. D. (2000). An investigation of mathematics and reading achievement of 5- through 14-year olds using latent growth curve methodology. Dissertation Abstracts International, A (Humanities and Social Sciences). Vol 60(12-A), 4323, US: Univ Microfilms International.

Thompson, R., Higgins, C., \& Howell, J. (1991). Personal Computing: Toward a Conceptual Model of Utilization. MIS Quarterly, 15(1), 125-143.

Trochim, W. (2006). Research Methods Knowledge Base. SRM. Retrieved Jun 18, 2017, from https://www.socialresearchmethods.net/kb/

ULLMAN MT. (2011). A neurocognitive perspective on language: The declarative/procedural model. Nature Reviews Neuroscience, 2, 717-726.

Venkatesh, V., \& Bala, H. (2008). Technology Acceptance Model 3 and a Research Agenda on Interventions. Decision Science, 39(2), 273-312.

Venkatesh, V., \& Davis, F. D. (2000). A theoretical extension of the technology acceptance 
model: Four longitudinal field studies. Management Science, 46(2), 186-204.

Venkatesh, V., Morris, M., Davis, G., \& Davis, F., (2003). User Acceptance of Information Technology: Toward a Unified View. Journal Storage (JSTOR), 27(3), 425-478. Retrieved Jun 17, 2017, from https://nwresearch.wikispaces.com/file/view/Venkatesh+User+Acceptance+of+Information+ Technology+2003.pdf

Verhoeven, J., Dirk, H., \& Kurt, D., (2010). Information and communication technologies in the life of university freshmen: An analysis of change. CENTRE FOR SOCIOLOGICAL RESEARCH, 55(1), pp.53-66. Retrieved Jun 18, 2017, from https://lirias.kuleuven.be/bitstream/123456789/260160/3/Information+and+communication+t echnologies+in+the+life+of+university+freshmen+self+archiving.pdf

Werner, P. (2004). Reasoned Action and Planned Behavior in Peterson S. J. \& Bredow T. S. (eds). Middle range Theories. Application to Nursing Research. Lippincott Williams \& Wilkins. Philadelphi, pp.125-147.

Wheaton, B., Muthén, B., Alwin, D. F., \& Summers, G. F. (1977). Assessing reliability and stability in panel models. In D. R. Heise (Ed.), Sociological methodology (pp. 84-136). San Francisco: Jossey-Bass.

Zahid, Wahid \& Dastane, Omkar. (2016). Factors Affecting Purchase Intention of South East Asian (SEA) Young Adults towards Global Smartphone Brands. ASEAN MARKETING JOURNAL. VIII. 66-84.

\section{Copyright}

Copyright for this article is retained by the author(s), with first publication rights granted to the journal.

This is an open-access article distributed under the terms and conditions of the Creative Commons Attribution license (http://creativecommons.org/licenses/by/4.0/). 